\begin{tabular}{c} 
Volume and Issues Obtainable at Center for Sustainability Research and Consultancy \\
Journal of Accounting and Finance in Emerging Economies \\
ISSN: 2519-0318 ISSN (E) 2518-8488 \\
Volume 6: Issue 1 March 2020 \\
CSRᄃ \\
Journal homepage: www.publishing.globalcsrc.org/jafee \\
\hline
\end{tabular}

\title{
A Tale of the Ticker; Stock Market Capacity Building Hegemony and Temporal Performance in the Emerging Economies
}

\author{
${ }^{1}$ Areeba Khan, ${ }^{2}$ Imran Sharif Chudhary, ${ }^{3}$ Sohail Saeed, ${ }^{4}$ Muhammad Kamran Shahid \\ ${ }^{1}$ Department of Management Sciences, The Islamia University of Bahawalpur, Pakistan \\ ${ }^{2}$ Dean/Director, School of Economics, Bahauddin Zakariya University, Multan, Pakistan / Putra Business School, \\ UPM, Malaysia \\ ${ }^{3}$ Department of Commerce, The Islamia University of Bahawalpur, Pakistan \\ ${ }^{4}$ Department of Management Sciences, The Islamia University of Bahawalpur, Pakistan
}

\begin{tabular}{l}
\multicolumn{1}{c}{ ARTICLE DETAILS } \\
\hline History \\
Revised format: February 2020 \\
Available Online: March 2020 \\
Keywords \\
Capacity Building, Stock Market \\
Capitalization, Economic Growth, \\
Gross Domestic Product, \\
Emerging Economies.
\end{tabular}

JEL Classification:

D24, D29, $L 11$

\begin{abstract}
This paper aims to examine stock market with a capacity building perspective for economic growth, focusing on the factors that enhance stock market capitalization in the long term. This study evaluates cross country series data of 26 emerging countries listed at MSCI index, through a period of 2006 to 2019. The data were collected through World Bank, Pakistan Stock Exchange and SECP database. Vector Error correction model and Multiple Regression analysis were applied on data to analyze the impact of assorted factors on stock market capitalization to GDP as a measure of long term capacity.

The findings suggest that political stability and corporate tax rate are two important factors that may have significant impact on stock market capitalization to GDP. This research is different from all past researches with respect to methodological, aeon and acclimatization perspective. Capacity building is a relatively new phenomenon adopted from complex adaptive ecosystems and most studies in this area are of theoretical nature. Moreover, the fact that this research has considered not only the long term but also shortterm market capitalization perspective, adds to its overall value and originality.
\end{abstract}

(C) 2020 The authors, under a Creative Commons Attribution-Non Commercial 4.0

Corresponding author's email address: imran@bzu.edu.pk

Recommended citation: Khan, A., Chudhary, I. S., Saeed, S. \& Shahid, M. K., (2020). A Tale of the Ticker; Stock Market Capacity Building Hegemony and Temporal Performance in the Emerging Economies. Journal of Accounting and Finance in Emerging Economies, 6 (1), 33-52

DOI: $10.26710 /$ jafee.v6i1.1060 


\section{Introduction}

'The market simply goes to prove that we still have loco weeds

For the bull buys what he doesn't want, and the bear sells what he needs

I bought an elevator stock, and thought that I'd done well

Then the little bears all ran downstairs, and rang the basement bell'

(Frank Crumit-A tale of the ticker)

Stock markets are epitome of volatility as they manage the flow of funds from savers to investors in highly agile instruments with multiscale systemic and non-systemic risks. They provide equity financing to investors and may prove instrumental in long run economic growth through pooling of institutional and individual savings. The lifecycle vis a vis permanent income theory postulates that individual wealth may increase as a result of surge in asset prices over the lifetime of an investor. Q theory also suggests a direct relationship between current and lagged asset prices and individual estimates of wealth. Therefore, both consumption and investment led theories of economic growth emphasize a sizeable and efficient market for determining asset prices at the core of capital allocation for economic growth (Iqbal, 2012).

Othman Abbas (2016) assimilates that stock market liquidity and development of banking sector of a country provides the needed capital which assists in bringing investment within the market and improves the general condition of an economy. Financial market contributes tolerably in making this possible. This study tends to find out, whether capacity building in stock exchanges of the country affect the economic growth? Also, that, what are the critical variables in capacity building of a stock market which contribute in enhancing the economic development of any country. Most of the studies in this field use a single stock market to concentrate and analyze the effects of stock market performance in the economy (Iqbal, 2012). Some of them also used aggregated stock markets of different countries and focus on other factors like size of the market and income level of the country. Many cross-country researches investigate the contribution of capital markets in building economy and agree that well organized and effective financial investments are better tools to be used for economic development. Othman Abbas (2016) also argues that with the rise of popularity of worldwide stock markets, risk sharing is inspired by the market players which subsequently supports the resource allocation and improves economic growth.

Stock market in Pakistan has been quite volatile in last three years. Stock price index fell in 2008 due the recession in capital markets of Pakistan. Stock market crashed in 2008 and stock price index reduced to 6,000 points from 14,000 points. As past theories reveal, by focusing on the relationship between capital markets and economy we may be able to diversify our risk and allocate our resources and investments efficiently. 
Figure 1. 1 Pakistan Karachi Stock Exchange Index Performance

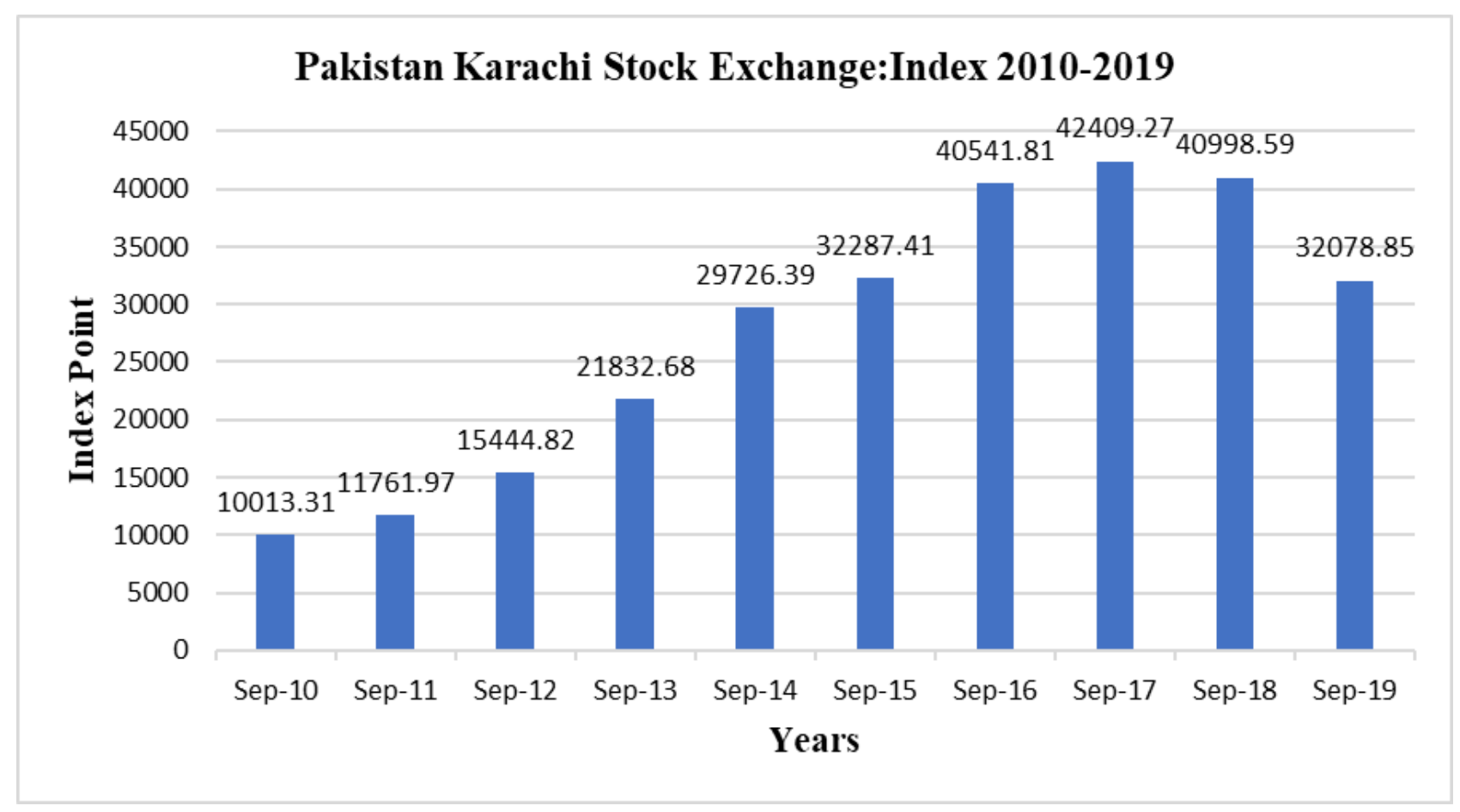

As per the world bank data, in 2001 the capitalization as per GDP was 21.42. Afterwards the percentage shows some downturn and falls to 15.25 in 2011. Eventually it shows some growth to the level of 19.46 in 2012. In 2013, market capitalization as per GDP shows further growth as compared to 2001 to the level of 24.79. Similarly, in 2014 it reaches a period high of 30.07 . The ratio starts declining in 2015 and reaches 24.42. The maximum flow of growth was achieved in 2016 at the level of 32.97, as shown in the graph given below.

Figure 1.2 Stock Market Capitalization as \% of GDP

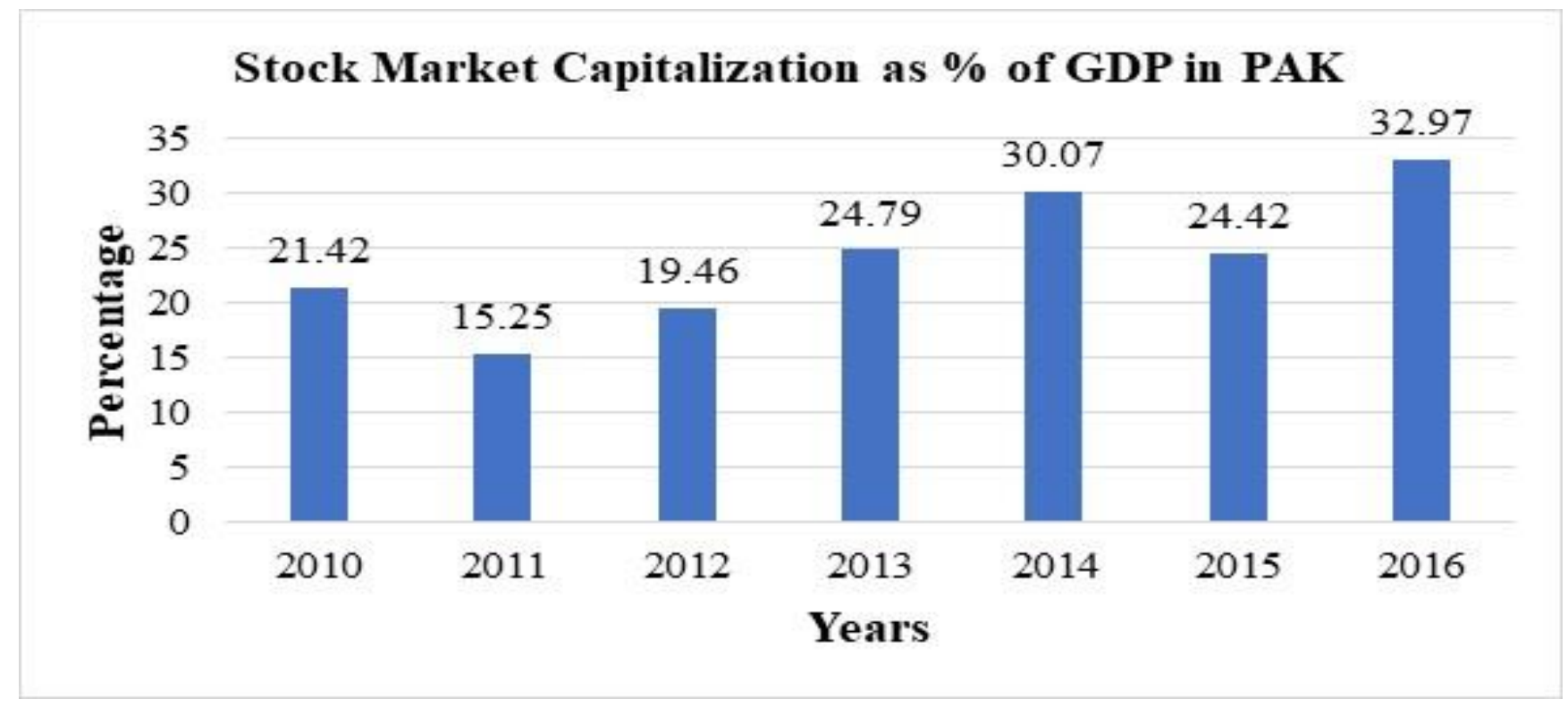




\section{Objectives of the Study}

- To identify capacity building momentum of Pakistan through GDP to market capitalization ratio.

- To identify factors responsible for stock market capacity building in Pakistan.

- To compare capacity building momentum of Pakistan with other economies of the same stature.

- To ascertain the impact of stock market capacity building on economic development.

\section{Statement of the problem}

Pakistan Stock Exchange (PSX) has witnessed an increase in its market growth and investment portfolio, but its registered points have experienced a decrease with the passage of time. PSX market growth and investment portfolio are not in line with the emerging market indices and it has continued to show a decreasing trend in most growth sectors in three past years.

Extensive literature has focused on efficiency and growth, but there aren't many studies in capacity building of financial markets. In absence of capacity building measures, growth and efficiency are also unattainable. Capacity building is a concept that mostly applies in complex ecological systems. The selfsustaining yet widely interdependent institutional existence of the financial system makes it similar to an ecosystem with the possibility of growth and change through capacity building. Therefore, we may borrow the concept of capacity building from complex ecological systems and leverage it to enhance opportunity of market growth through depth of investment portfolio in a stock market like PSX.

\section{Review of Literature}

Stock market not only provide the function of mobilization of savings from savers to investors but they also propel growth in wealth by liquidity, risk and information management of idiosyncratic risks and an austere governance and control mechanism (Othman, 2016). Levine (1997) reflects on how stock markets provide for risk arbitrage and protect investors through provision of options like liquidity and diversity in investment portfolio, thereby increasing the Sharpe's ratio to risk and return (Nazir, Nawaz, \& Gilani 2001). This risk arbitrage mechanism increases firm efficiency through reduction of uneconomical linkages and promotion of specialization (Delali 2007).

Government interventions through fiscal policies also effect the level of economic activity in a country and therefore the regional stock markets. Looking through the capacity building lens, the bi-causality of this relationship is evident where stock market reactions to fiscal policy measures determine the capital allocation capacity to various asset classes impeding or fostering economic growth (Foresti \& Napolitano 2017). These changes in asset prices through reactions to fiscal policy incentives may be positive or negative, depending upon nature of intervention or level of market development.

Perveen \& Rahman (2018) carried out a detailed study on stock market reactions to monetary and fiscal policy interventions in Tehran during the period 2006-2012. The results of their study suggest that money supply has a negative impact on stock exchange index, developmental expenditures have a positive impact and exchange rate volatility has a significantly negative impact on stock exchange performance. Same results were conferred by Foresti \& Napolitano in their study carried out in 2017.

MAO and WU (2007) in their study on EU countries, studied the impact of monetary and fiscal policy changes on stock market. They used equity returns and the impact of macroeconomic factors on stock yields. The study concluded a correlation between inflation (CPI), real and nominal interest rates, exchange rates and stock market return in European markets, whereas emerging markets showed relatively volatile reactions to the fiscal interventions by the Government.

Interest rate has been identified as the critical factor in determining stock market yield, hence an important tool for prospective capacity building measures (MAO and WU, 2007). Hariz et al. (2017) 
conclude that supply of funds is grossly increased with an increase in the interest rate, thereby adding to individual wealth. The debt funds theory of interest rate promulgates the same view considering every other factor is held constant. This view is contrary to Keynes who described interest rates as an outcome of liquidity preference theory thereby establishing supply and demand as pivotal factors in determining interest rates (Moyo \& Le Roux, 2018). Keynes (1965) also identified scheduled Government expenditure as a determinant of interest rates. Demand and supply factors (Fisher, 1930) financial reforms, economic growth (Hariz et al., 2017) lending and borrowing spread (Saeed, 2017) GDP, inflation and political stability are few of the factors which may have an impact on supply and demand of funds and the growth capacity of the stock market.

Following hypothesis could be inferred from the review of pertinent literature:

H1: Inflation (CPI) has a significant impact on the GDP to stock market capitalization ratio.

H2: Political Stability has a significant impact on the GDP to stock market capitalization ratio.

H3: Interest Rate has a significant impact on the GDP to stock market capitalization ratio.

H4: Corporate Tax Rate has a significant impact on the GDP to stock market capitalization ratio.

H5: Indirect Tax Rate has a significant impact on the GDP to stock market capitalization ratio. 
Table 2. 1 Table of Variable Description

\begin{tabular}{|c|c|c|c|}
\hline Variables & Description & Measurement & Source \\
\hline Inflation & $\begin{array}{l}\text { Inflation is a quantitative measure of } \\
\text { the rate at which the average price } \\
\text { level of a basket of selected goods and } \\
\text { services in an economy increases over } \\
\text { a period. It is the constant rise in the } \\
\text { general level of prices where a unit of } \\
\text { currency buys less than it did in prior } \\
\text { periods. Often expressed as a } \\
\text { percentage, inflation indicates a } \\
\text { decrease in the purchasing power of a } \\
\text { nation's currency. }\end{array}$ & $\begin{array}{l}\text { Real Inflation, year to } \\
\text { year, measure through } \\
\text { consumer price index }\end{array}$ & $\begin{array}{l}\text { World Bank Data base, } \\
\text { Pakistan Stock Exchange } \\
\text { SECP } \\
\text { The Global Economy }\end{array}$ \\
\hline $\begin{array}{c}\text { Political } \\
\text { stability } \\
\text { (Perveen and } \\
\text { Rahman 2018) }\end{array}$ & $\begin{array}{l}\text { Political uncertainty (also called } \\
\text { regime uncertainty) is a class of } \\
\text { economic risk where the future path } \\
\text { of government policy is uncertain, } \\
\text { raising risk premia and leading } \\
\text { businesses and individuals to delay } \\
\text { spending and investment until this } \\
\text { uncertainty has been resolved. } \\
\text { Political uncertainty may refer to } \\
\text { uncertainty about monetary or fiscal } \\
\text { policy, the tax or regulatory regime, } \\
\text { or uncertainty over electoral outcomes } \\
\text { that will influence political leadership. }\end{array}$ & $\begin{array}{l}\text { Political Stability Index } \\
\text { (-2.5 weak, } 2.5 \text { strong) }\end{array}$ & $\begin{array}{l}\text { World Bank Data base, } \\
\text { Pakistan Stock Exchange } \\
\text { SECP } \\
\text { The Global Economy }\end{array}$ \\
\hline $\begin{array}{l}\text { Interest Rate/ } \\
\text { Bond yield } \\
\text { (Shula 2017; } \\
\text { Moyo and Le } \\
\text { Roux 2018) }\end{array}$ & $\begin{array}{l}\text { An interest rate is the percentage of } \\
\text { principal charged by the lender for the } \\
\text { use of its money. The principal is the } \\
\text { amount of money lent. As a result, } \\
\text { banks pay you an interest rate on } \\
\text { deposits. They are borrowing that } \\
\text { money from you. }\end{array}$ & Yearly Interest Rate & $\begin{array}{l}\text { World Bank Data base. } \\
\text { Pakistan Stock Exchange. } \\
\text { SECP } \\
\text { The Global Economy }\end{array}$ \\
\hline Fiscal Policy & $\begin{array}{l}\text { In economics and political science, } \\
\text { fiscal policy is the use of government } \\
\text { revenue collection (taxes or tax cuts) } \\
\text { and Fiscal policy is based on the } \\
\text { theories of the British economist John } \\
\text { Maynard Keynes, whose Keynesian } \\
\text { economics indicated that government } \\
\text { changes in the levels of taxation and } \\
\text { government spending influences } \\
\text { aggregate demand and the level of }\end{array}$ & $\begin{array}{l}\text { Dummy Variable } \\
0 \text { Loosening and } 1 \\
\text { tightening. }\end{array}$ & $\begin{array}{l}\text { World Bank Data base, } \\
\text { Pakistan Stock Exchange } \\
\text { SECP } \\
\text { The Global Economy }\end{array}$ \\
\hline
\end{tabular}




\section{Conceptual Framework}

Figure 2. 1 Framework

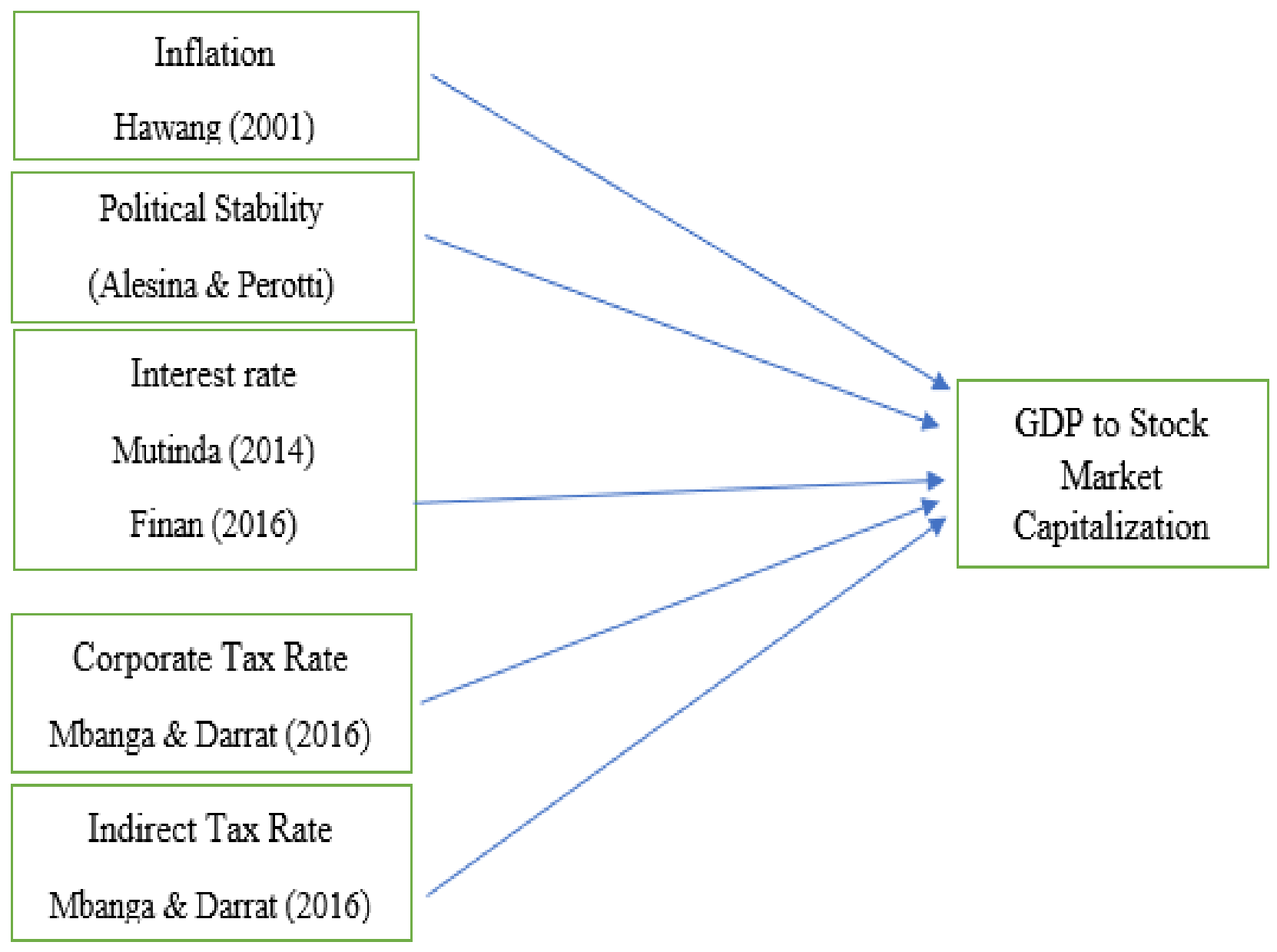

\section{Method}

The study seeks to identify and describe the relationship between market capitalization and economic growth in Pakistan. The study primarily relies on secondary data on market capitalization and economic growth over the period 2006 to 209 annually. In 2012 Dorko while undertaking a similar research study also used secondary Data. The data is sourced from World Bank data base, The Global Economy Security and Exchange Commission of Pakistan (SECP) and Pakistan Stock Exchange (PSX).

Stock market capitalization to GDP (SMC) is taken as a dependent variable and Political stability (PS), Real interest rate (RIR), Inflation consumer price index (CPI), Corporate tax rate (CTR) and Indirect tax rate (ITR) are taken as independent variables. All data are collected from World bank database, Pakistan Stock Exchange (PSE), Security and exchange commission of Pakistan (SECP) and The Global Economy from 2006 to 2019 including twenty-six (26) emerging countries. These 26 emerging countries include Pakistan, China, India, Indonesia, Korea, Malaysia, Philippines, Taiwan, Thailand, Czech Republic, Egypt, Greece, Hungary, Poland, Qatar, Russia, Saudi Arabia, South Africa, Turkey, UAE, Argentina, Brazil, Chile, Colombia, Mexico, and Peru. 
All variables from 2006 to 2010 of emerging economies are used collectively to analysis the Vector Error Collection model (VECM), Secondly, for VECM there are three slab groups (1-40, 40-70, 70+). These groups are made by using the data of SMC from 2018 and 2019 of 26 emerging countries as a base for all other variables. With respect to SMC three slabs groups with countries are formulated; 0-40 group (Pakistan, Egypt, Greece, Hungary, Poland, Russia, Turkey, Argentina, Colombia and Mexico) 40-70 group (China, Indonesia, Saudi Arabia, UAE, Brazil and Peru) 70+ group (India, Korea, Malaysia, Philippines, Taiwan, Thailand, Qatar, South Africa and Chile). This analysis is run in three steps on the bases of group slabs (Soydemir 2000).

Vector autoregression (VAR) model was introduced by the macro econometrician Christopher Sims (1980) to model the joint dynamics and causal relations among a gaggle of macroeconomic variables. VAR models are useful for forecasting. Consider a univariate autoregressive model - for instance, an AR (1) $\mathrm{Yt}=\alpha+\beta \mathrm{Yt}-1+\mathrm{Ct}$-which describes the dynamics of only one variate $\mathrm{Y} t$ (i.e., national income) as a linear process of its own past (Soydemir 2000)

A vector error correction model (VECM) may be a restricted VAR designed to be used with nonstationary series that are known to be cointegrated. Cointegration may be tested through use of VAR object or equation object. This process makes use of non-stationary regression analysis (Saeed 2017).

\section{Results and Discussion}

This section includes different techniques like Vector autoregression, Vector error correction model and descriptive statistics for the analysis of data. It includes the impact of Political stability, Inflation, Real interest rate, Corporate tax rate and Indirect tax rate on the Stock market capitalization to GDP during 2006-2019 of twenty-sex emerging countries, and analysis of Pakistan along with the interpretation of the results.

The use of the stock market capitalization-to-GDP ratio as a measure of capacity building is new for the field of finance. This ratio is also known as Warren Buffet ratio since he called it the only reliable measure of stock market valuation. This ratio measures capacity of a stock market by comparison of total value of all publicly traded stocks in a market and the economy's gross domestic production (GDP). The ratio might also be called the measure of aggregate financial equity to value of country's total output. The result of this calculation is the percentage of GDP which represents the volume of equity raised by the stock market.

The percentage representation of ratio is the hegemonic measure used to decide if the market is overvalued or undervalued. Generally, a ratio percentage of above $100 \%$ would represent an overvalued market and a ratio percentage of $50 \%$ or less would indicate undervaluation. Ratio percentage rom $50 \%$ to $75 \%$ is modestly undervalued whereas $75 \%$ to $90 \%$ is considered fair value. 
Figure 4.1 Stock Market Capitalization to GDP ratio of Pakistan

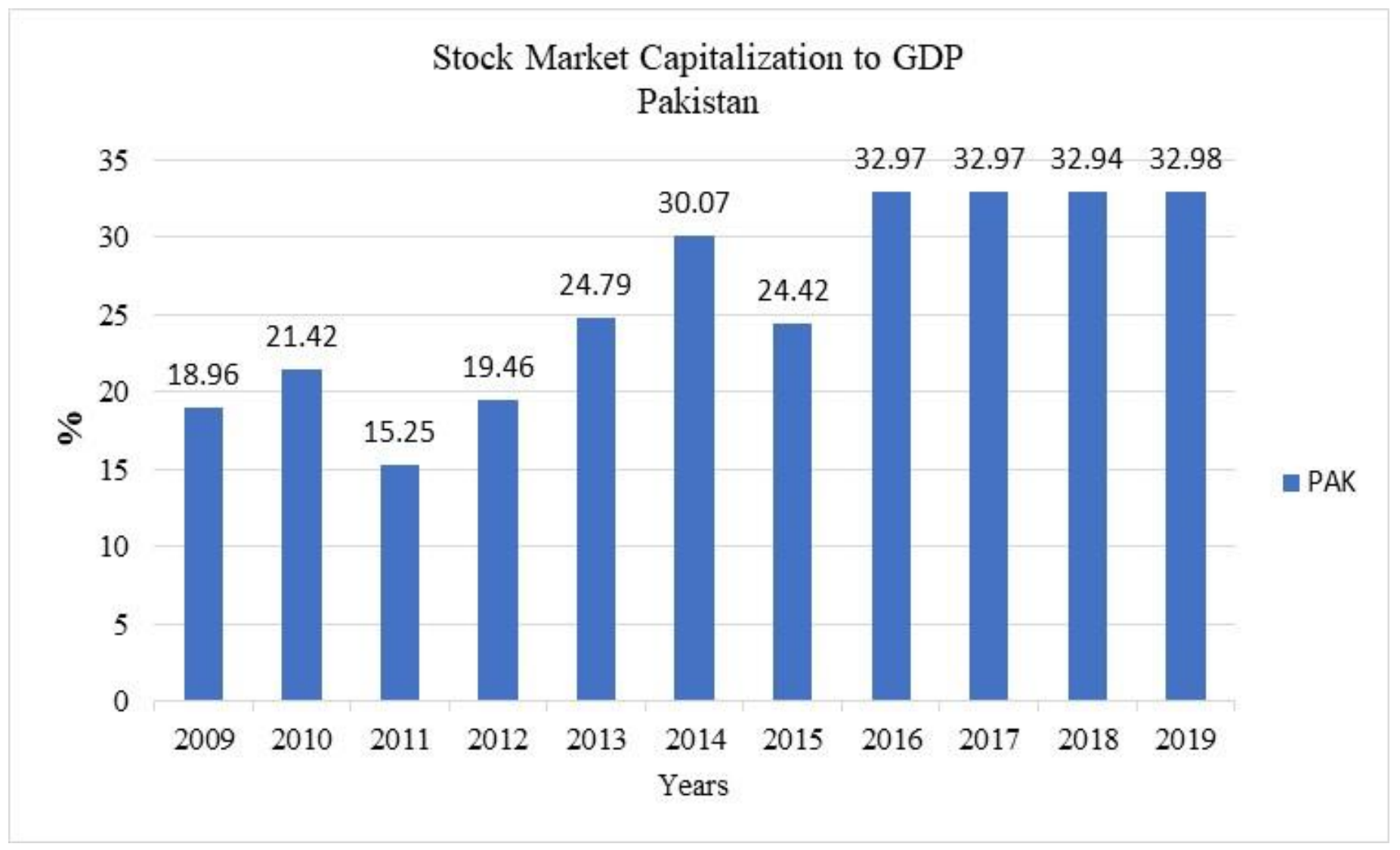

Figure 4. 2 Stock Market Capitalization to GDP (0-40 Group)

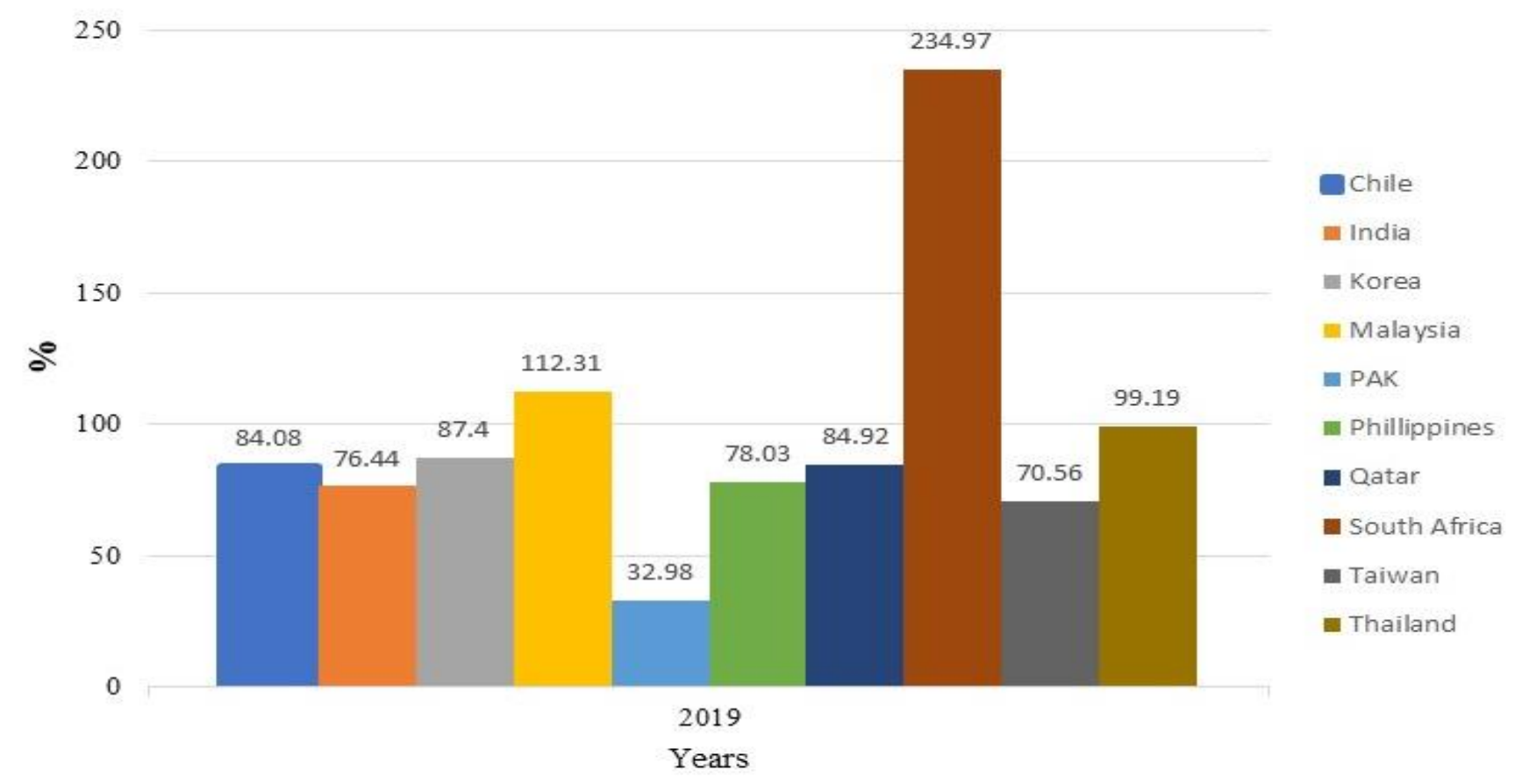


The average for 209 of all 0-40 emerging countries group is 23.93 percent. The highest value is in Pakistan at 32.98 percent and the lowest value is in Argentina at 8.87 percent as shown in the above chart of 0-40 emerging countries group. In the above chart 2, there are those countries whose SMC is below $40 \%$, and all are undervalued countries.

Figure 4. 3: Stock Market Capitalization to GDP 40-70 Group

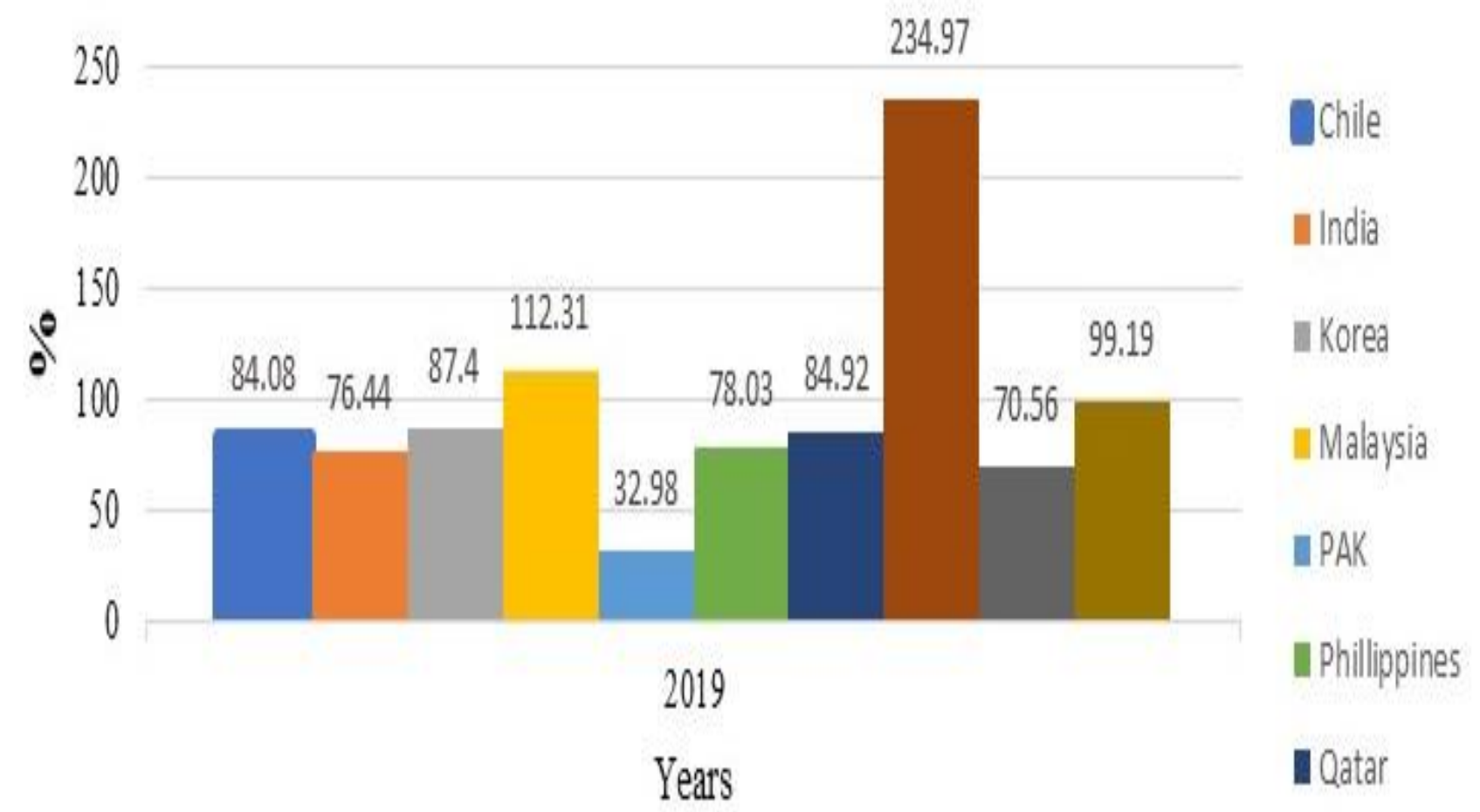

The average for 2019 of all 40-70 emerging countries group is 48.22 percent. The highest value is in Saudi Arabia at 63.44 percent and the lowest value is in Pakistan at 32.98 percent as shown in the above graph. There are those countries whose SMC is above $40 \%$, and all are undervalued countries as they all round about 50\%. Out of all countries in the figure 4.3, Saudi Arabia and UAE are modestly undervalued.

Figure 4. 4: Stock Market Capitalization to GDP 70+ Group

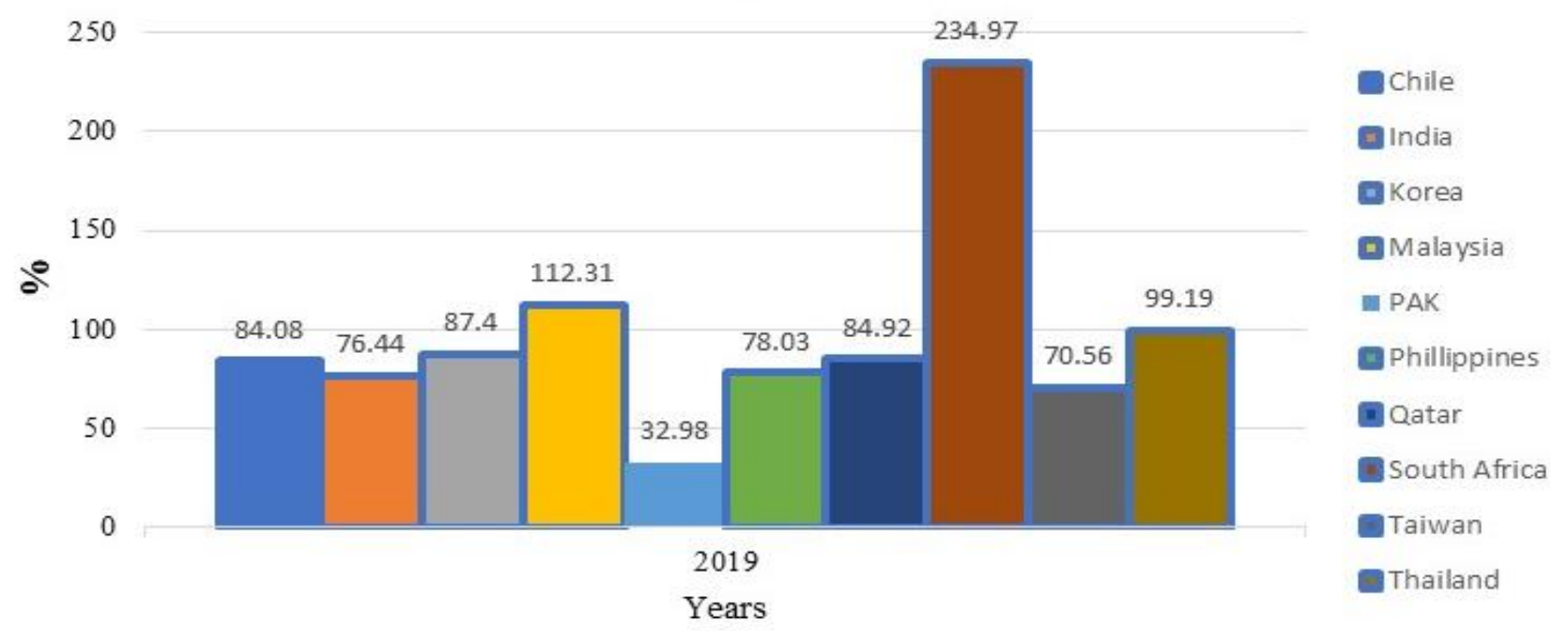


The average for 2019 of all 70+ emerging countries group is 96.09 percent. The highest value is in South Africa at 234.97 percent and the lowest value is in Pakistan at 32.98 percent as shown in the above chart of 70+ emerging countries group. Taiwan is modestly undervalued as per figure 4.4. Also, the market may be fair valued if the ratio falls between 75 and $90 \%$ so Chile, India, Korea, Philippines, Qatar and Thailand are fair valued countries.

Table 4.1 : Descriptive Statistic of Pak

\begin{tabular}{|c|c|c|c|c|c|c|}
\hline \multicolumn{7}{|c|}{ Descriptive Statistic } \\
\hline & SMC_PAK & PS_PAK & CPI_PAK & RIR_PAK & CTR_PAK & ITR_PAK \\
\hline Mean & 26.024 & $(2.546)$ & 7.435 & 3.646 & 33.182 & 16.636 \\
\hline Median & 24.790 & $(2.480)$ & 7.200 & 4.693 & 34.000 & 17.000 \\
\hline Maximum & 32.980 & $(2.400)$ & 13.600 & 8.321 & 35.000 & 17.000 \\
\hline Minimum & 15.250 & $(2.810)$ & 2.500 & $(5.079)$ & 30.000 & 16.000 \\
\hline Std. Dev. & 6.662 & 0.142 & 3.917 & 4.420 & 2.089 & 0.505 \\
\hline Skewness & $(0.206)$ & $(0.484)$ & 0.326 & $(1.196)$ & $(0.528)$ & $(0.567)$ \\
\hline Kurtosis & 1.556 & 1.923 & 1.636 & 3.076 & 1.645 & 1.321 \\
\hline Jarque-Bera & 1.033 & 0.960 & 1.048 & 2.627 & 1.353 & 1.881 \\
\hline Probability & 0.597 & 0.619 & 0.592 & 0.269 & 0.508 & 0.390 \\
\hline
\end{tabular}

The mean value of SMC for Pakistan is 26.024, and as per this description the value of SMC_PAK lies between 15.250 to 32.980 . The average distance of SMC_PAK between a single observation and the mean is 6.662 in emerging countries.

\subsubsection{Vector Error Correction Estimates (PAK)}

In Vector error correction model (VECM Stock market capitalization to GDP (SMC_PAK) is used as a dependent variable and Political stability (PS_PAK), Real interest rate (RIR_PAK), Inflation consumer price index (CPI_PAK), Corporate tax rate (CTR_PAK) and Indirect tax rate (ITR) are used as independent variables.

Table 4. 2: Vector Error Correction Estimates Pak

\begin{tabular}{|c|c|}
\hline \multicolumn{2}{|c|}{ V ector Error Correction Estimates } \\
\hline Cointegrating Eq : & Coin tEq $\mathbf{~}$ \\
\hline SMC_PAK(-1) & 1.000 \\
\hline & 1.664 \\
CTR_PAK (-1) & $0.030)$ \\
& {$[54.609]$} \\
\hline \multirow{2}{*}{ ITR_PAK (-1) } & -3.455 \\
& $(0.206)$ \\
\hline C & {$[-16.773]$} \\
\hline
\end{tabular}




\begin{tabular}{|c|c|c|c|}
\hline Error Correction & D(SMC_PAK) & D(CTR_PAK) & D(IT R_PAK) \\
\hline \multirow{3}{*}{ CointEq1 } & -2.287 & 0.024 & 0.012 \\
& $(0.407)$ & $(0.070)$ & $(0.089)$ \\
& {$[-5.625]$} & {$[0.347]$} & {$[0.138]$} \\
\hline \multirow{3}{*}{ C } & 102.744 & -9.149 & -2.049 \\
& $(26.603)$ & $(4.586)$ & $(5.815)$ \\
& {$[3.862]$} & {$[-1.99]$} & {$[-0.353]$} \\
\hline \multirow{2}{*}{ PS_PAK } & 37.259 & -3.083 & -0.776 \\
& $(9.724)$ & $(1.67)$ & $(2.126)$ \\
& {$[3.831]$} & {$[-1.839]$} & {$[-0.365]$} \\
\hline \multirow{2}{*}{ CPI_PAK } & -0.467 & 0.081 & 0.009 \\
& $(0.219)$ & $(0.038)$ & $(0.048)$ \\
& {$[-2.133]$} & {$[2.151]$} & {$[0.179]$} \\
\hline \multirow{2}{*}{ RIR_PAK } & -0.804 & 0.061 & 0.027025 \\
& $(0.392)$ & $(0.068)$ & $(0.086)$ \\
\hline R-squared & {$[-2.052]$} & {$[0.901]$} & {$[0.316]$} \\
\hline Adj. R-squared & 0.912 & 0.787 & 0.050 \\
\hline F-statistic & 0.842 & 0.617 & -0.709 \\
\hline Determinant resid covariance (dof adj.) & 4.628 & 0.066 \\
\hline
\end{tabular}

The output obtained from the analysis is shown in above table 5. The vector error correction equation is as follows:

VECM: $\Delta Y=\beta_{o}+\sum_{i=1}^{n} \beta_{i} \Delta Y_{t-i}+\sum_{i=0}^{n} \delta_{i} \Delta X_{t-i}+\vartheta Z_{t-1}+\mu_{i}$

From results the cointegrating equation coefficient is -2.287 for the error correction term with no lags and coefficient values of $x$ for this lag are PS_PAK= 37.259, CPI_PAK=-0.467, RIR_PAK=-0.804 and the constant $\mathrm{c}$ is 102.744 .

The cointegrating equation for the long run model is also shown as follows:

$Z_{t-1}=E C T_{t-1}=Y_{t-1}-\beta_{0}-\beta_{1} X_{t-1}$

In the results the value of SMC_PAK $(-1)=1.000$, CTR_PAK $(-1)=1.664$ and ITR_PAK (-1) -3.454 for the lag period zero and constant ( $\left.\beta \_0\right)$ for the cointegrating equation is -23.736 .

The R-squared is $91 \%$ for this lag period and Adj. R-squared is $84 \%$ that predicted a good value, this variance is obtaining by testing different combination of endogenous and exogenous variables. 


\subsubsection{Unrestricted Vector Autoregression (VAR 0-40)}

Table 4. 3: Unrestricted Vector Autoregression (0-40)

\begin{tabular}{|c|c|c|c|c|c|c|}
\hline \multicolumn{7}{|c|}{ Unrestricted Vector Autoregression (VAR 0-40) } \\
\hline & SMC & PS & CPI & RIR & CTR & ITR \\
\hline SMC (-1) & $\begin{array}{l}0.513972 \\
(0.17170) \\
{[2.99335]}\end{array}$ & $\begin{array}{l}0.006734 \\
(0.00468) \\
{[1.44015]}\end{array}$ & $\begin{array}{l}-0.121278 \\
(0.10640) \\
{[-1.13980]}\end{array}$ & $\begin{array}{l}-0.140213 \\
(0.07433) \\
{[-1.88644]}\end{array}$ & $\begin{array}{l}-0.051478 \\
(0.04469) \\
{[-1.15178]}\end{array}$ & $\begin{array}{l}0.005081 \\
(0.02171) \\
{[0.23409]}\end{array}$ \\
\hline SMC (-2) & $\begin{array}{l}0.158221 \\
(0.17053) \\
{[0.92784]}\end{array}$ & $\begin{array}{l}-0.006030 \\
(0.00464) \\
{[-1.29860]}\end{array}$ & $\begin{array}{l}0.141848 \\
(0.10567) \\
{[1.34233]}\end{array}$ & $\begin{array}{l}0.161768 \\
(0.07382) \\
{[2.19148]}\end{array}$ & $\begin{array}{l}-0.025252 \\
(0.04439) \\
{[-0.56891]}\end{array}$ & $\begin{array}{l}-0.020156 \\
(0.02156) \\
{[-0.93502]}\end{array}$ \\
\hline PS (-1) & $\begin{array}{l}4.704016 \\
(6.83003) \\
{[0.68873]}\end{array}$ & $\begin{array}{l}0.400689 \\
(0.18599) \\
{[2.15441]}\end{array}$ & $\begin{array}{l}-10.43934 \\
(4.23249) \\
{[-2.46647]}\end{array}$ & $\begin{array}{l}-3.207232 \\
(2.95657) \\
{[-1.08478]}\end{array}$ & $\begin{array}{l}4.067862 \\
(1.77785) \\
{[2.28808]}\end{array}$ & $\begin{array}{l}-0.188740 \\
(0.86340) \\
{[-0.21860]}\end{array}$ \\
\hline PS (-2) & $\begin{array}{l}-3.292768 \\
(6.60077) \\
{[-0.49885]}\end{array}$ & $\begin{array}{l}0.539324 \\
(0.17974) \\
{[3.00054]}\end{array}$ & $\begin{array}{l}9.255757 \\
(4.09042) \\
{[2.26279]}\end{array}$ & $\begin{array}{l}2.466244 \\
(2.85733) \\
{[0.86313]}\end{array}$ & $\begin{array}{l}-3.294821 \\
(1.71817) \\
{[-1.91763]}\end{array}$ & $\begin{array}{l}0.125415 \\
(0.83442) \\
{[0.15030]}\end{array}$ \\
\hline CPI (-1) & $\begin{array}{l}0.197090 \\
(0.25363) \\
{[0.77709]}\end{array}$ & $\begin{array}{l}-0.006130 \\
(0.00691) \\
{[-0.88763]}\end{array}$ & $\begin{array}{l}0.855878 \\
(0.15717) \\
{[5.44559]}\end{array}$ & $\begin{array}{l}0.120640 \\
(0.10979) \\
{[1.09883]}\end{array}$ & $\begin{array}{l}-0.101871 \\
(0.06602) \\
{[-1.54306]}\end{array}$ & $\begin{array}{l}-0.034067 \\
(0.03206) \\
{[-1.06256]}\end{array}$ \\
\hline CPI (-2) & $\begin{array}{l}0.357377 \\
(0.27047) \\
{[1.32131]}\end{array}$ & $\begin{array}{l}-0.019758 \\
(0.00737) \\
{[-2.68271]}\end{array}$ & $\begin{array}{l}-0.450990 \\
(0.16761) \\
{[-2.69073]}\end{array}$ & $\begin{array}{l}-0.019032 \\
(0.11708) \\
{[-0.16255]}\end{array}$ & $\begin{array}{l}0.189191 \\
(0.07040) \\
{[2.68722]}\end{array}$ & $\begin{array}{l}-0.022792 \\
(0.03419) \\
{[-0.66662]}\end{array}$ \\
\hline RIR (-1) & $\begin{array}{l}0.314125 \\
(0.35397) \\
{[0.88743]}\end{array}$ & $\begin{array}{l}0.000259 \\
(0.00964) \\
{[0.02682]}\end{array}$ & $\begin{array}{l}0.207820 \\
(0.21935) \\
{[0.94743]}\end{array}$ & $\begin{array}{l}0.782232 \\
(0.15323) \\
{[5.10507]}\end{array}$ & $\begin{array}{l}-0.042330 \\
(0.09214) \\
{[-0.45942]}\end{array}$ & $\begin{array}{l}-0.000815 \\
(0.04475) \\
{[-0.01821]}\end{array}$ \\
\hline $\operatorname{RIR}(-2)$ & $\begin{array}{l}-0.038973 \\
(0.32337) \\
{[-0.12052]}\end{array}$ & $\begin{array}{l}0.001786 \\
(0.00881) \\
{[0.20282]}\end{array}$ & $\begin{array}{l}-0.197049 \\
(0.20039) \\
{[-0.98334]}\end{array}$ & $\begin{array}{l}-0.146482 \\
(0.13998) \\
{[-1.04645]}\end{array}$ & $\begin{array}{l}0.132544 \\
(0.08417) \\
{[1.57467]}\end{array}$ & $\begin{array}{l}0.017199 \\
(0.04088) \\
{[0.42074]}\end{array}$ \\
\hline $\operatorname{CTR}(-1)$ & $\begin{array}{l}1.079929 \\
(0.63695) \\
{[1.69548]}\end{array}$ & $\begin{array}{l}-0.029265 \\
(0.01734) \\
{[-1.68732]}\end{array}$ & $\begin{array}{l}-0.285412 \\
(0.39471) \\
{[-0.72310]}\end{array}$ & $\begin{array}{l}0.190101 \\
(0.27572) \\
{[0.68947]}\end{array}$ & $\begin{array}{l}0.834730 \\
(0.16580) \\
{[5.03467]}\end{array}$ & $\begin{array}{l}-0.069454 \\
(0.08052) \\
{[-0.86259]}\end{array}$ \\
\hline CTR (-2) & -0.770229 & 0.018543 & 0.290969 & -0.136833 & 0.063860 & 0.001284 \\
\hline
\end{tabular}


From the above table, the SMC strongly influences ascensive by the t-statistics of 2.99 for lag interval 1.but for the lag interval $2 \mathrm{SMC}$ is not ascensive. The PS for the lag interval 1 and 2 does not predict or influence the SMC. CPI for the lag interval 1 not influence the SMC, but for the lag interval 2 influence the SMC with 1.321. RIR for the lag interval 1 and 2, does not influence the SMC. CTR for the lag interval 1 influences the SMC with 1.695, but no impact for the lag interval 2. ITR for the lag interval 2 influences the SMC with 1.495 and ITR for lag interval 2 has no impact. Similarly, the impact of SMC, PS, CPI, RIR, CTR and ITR for other equation is shown in the above output table. SMC have $51.40 \%$ and $15.82 \%$ increase in the SMC on average for the lag interval 1 and 2. CPI have $19.70 \%$ and $35.74 \%$ increase in the SMC on average for the lag interval 1 and 2. RIR have 31.4\% increase in the SMC for the lag interval 1. PS and CTR have $470 \%$ and $107 \%$ increase in the SMC for the lag interval 1. Similarly, for all other equation the impact of IVs is shown in the above output table.

\subsubsection{VECM (0-40)}

In this VECM analysis the results obtain from analysis are:

Table 4. 4: Vector Error Correction Estimates (0-40 Group)

\begin{tabular}{|c|c|c|c|c|c|c|}
\hline \multicolumn{7}{|c|}{ Vector Error Correction Estimates } \\
\hline Cointegrating Eq: & \multicolumn{6}{|c|}{ CointEq1 } \\
\hline $\operatorname{SMC}(-1)$ & \multicolumn{6}{|c|}{1.000} \\
\hline \multirow[b]{3}{*}{ PS $(-1)$} & \multicolumn{6}{|c|}{8.594} \\
\hline & \multicolumn{6}{|c|}{ (3.543) } \\
\hline & \multicolumn{6}{|c|}{ [2.425] } \\
\hline \multirow[b]{3}{*}{ CPI (-1) } & \multicolumn{6}{|c|}{7.651} \\
\hline & \multicolumn{6}{|c|}{$(0.403)$} \\
\hline & \multicolumn{6}{|c|}{ [19.00] } \\
\hline \multirow[b]{3}{*}{$\operatorname{RIR}(-1)$} & \multicolumn{6}{|c|}{$(1.259)$} \\
\hline & \multicolumn{6}{|c|}{$(0.617)$} \\
\hline & \multicolumn{6}{|c|}{$[-2.042]$} \\
\hline \multirow[b]{3}{*}{ CTR (-1) } & \multicolumn{6}{|c|}{3.233} \\
\hline & \multicolumn{6}{|c|}{$(0.516)$} \\
\hline & \multicolumn{6}{|c|}{ [6.268] } \\
\hline \multirow[b]{3}{*}{$\operatorname{ITR}(-1)$} & \multicolumn{6}{|c|}{6.239} \\
\hline & \multicolumn{6}{|c|}{$(1.048)$} \\
\hline & \multicolumn{6}{|c|}{$[5.952]$} \\
\hline $\mathrm{C}$ & \multicolumn{6}{|c|}{$(266.381)$} \\
\hline Error Correction: & D(SMC) & D(PS) & D(CPI) & D(RIR) & D(CTR) & D(ITR) \\
\hline \multirow[b]{3}{*}{ CointEq1 } & 0.105 & $(0.005)$ & $(0.098)$ & 0.039 & 0.000 & $(0.014)$ \\
\hline & $(0.027)$ & $(0.000)$ & $(0.008)$ & $(0.011)$ & $(0.009)$ & $(0.004)$ \\
\hline & [3.912] & [-10.47] & [-12.23] & [3.560] & [0.038] & [-3.873] \\
\hline \multirow[b]{3}{*}{$\mathrm{D}(\mathrm{SMC}(-1))$} & $(0.160)$ & 0.005 & $(0.088)$ & $(0.201)$ & $(0.049)$ & 0.020 \\
\hline & $(0.158)$ & $(0.003)$ & $(0.047)$ & $(0.064)$ & $(0.052)$ & $(0.021)$ \\
\hline & {$[-1.011]$} & [1.862] & [-1.879] & {$[-3.144]$} & [-0.938] & [0.927] \\
\hline \multirow[b]{3}{*}{$\mathrm{D}(\mathrm{SMC}(-2))$} & $(0.037)$ & $(0.003)$ & 0.021 & $(0.105)$ & $(0.094)$ & $(0.007)$ \\
\hline & $(0.187)$ & $(0.003)$ & $(0.056)$ & $(0.075)$ & $(0.062)$ & $(0.025)$ \\
\hline & {$[-0.199]$} & {$[-0.835]$} & {$[0.385]$} & {$[-1.385]$} & {$[-1.524]$} & {$[-0.266]$} \\
\hline \multirow[b]{2}{*}{$\mathrm{D}(\mathrm{PS}(-1))$} & $(3.460)$ & $(0.391)$ & $(2.395)$ & $(2.283)$ & 4.752 & 0.544 \\
\hline & (7.157) & $(0.128)$ & (2.131) & (2.895) & (2.369) & $(0.958)$ \\
\hline
\end{tabular}




\begin{tabular}{|c|c|c|c|c|c|c|}
\hline \multirow[b]{3}{*}{$\mathrm{D}(\mathrm{PS}(-2))$} & $(4.645)$ & $(0.231)$ & 4.266 & 0.322 & $(4.006)$ & $(0.646)$ \\
\hline & $(6.976)$ & $(0.125)$ & $(2.077)$ & $(2.822)$ & $(2.309)$ & $(0.934)$ \\
\hline & {$[-0.666]$} & {$[-1.852]$} & [2.053] & {$[0.114]$} & {$[-1.734]$} & {$[-0.691]$} \\
\hline \multirow[b]{3}{*}{$\mathrm{D}(\mathrm{CPI}(-1))$} & 0.169 & 0.005 & 0.062 & $(0.083)$ & $(0.246)$ & $(0.007)$ \\
\hline & $(0.366)$ & $(0.007)$ & $(0.109)$ & $(0.148)$ & $(0.121)$ & $(0.049)$ \\
\hline & {$[0.461]$} & {$[0.754]$} & {$[0.564]$} & {$[-0.560]$} & {$[-2.027]$} & {$[-0.152]$} \\
\hline \multirow[b]{3}{*}{$\mathrm{D}(\mathrm{CPI}(-2))$} & 0.440 & $(0.002)$ & $(0.207)$ & $(0.113)$ & 0.184 & 0.031 \\
\hline & $(0.284)$ & $(0.005)$ & $(0.085)$ & $(0.115)$ & $(0.094)$ & $(0.038)$ \\
\hline & [1.549] & {$[-0.375]$} & {$[-2.447]$} & {$[-0.981]$} & [1.961] & [0.825] \\
\hline \multirow[b]{3}{*}{$\mathrm{D}(\operatorname{RIR}(-1))$} & $(0.156)$ & $(0.006)$ & 0.176 & $(0.200)$ & $(0.182)$ & $(0.040)$ \\
\hline & $(0.353)$ & $(0.006)$ & $(0.105)$ & $(0.143)$ & $(0.117)$ & $(0.047)$ \\
\hline & {$[-0.441]$} & {$[-0.922]$} & [1.671] & {$[-1.404]$} & {$[-1.557]$} & {$[-0.849]$} \\
\hline \multirow[b]{3}{*}{$\mathrm{D}(\operatorname{RIR}(-2))$} & $(0.056)$ & $(0.003)$ & 0.021 & $(0.105)$ & 0.075 & $(0.013)$ \\
\hline & $(0.269)$ & $(0.005)$ & $(0.080)$ & $(0.109)$ & $(0.089)$ & $(0.036)$ \\
\hline & {$[-0.208]$} & {$[-0.685]$} & {$[0.265]$} & {$[-0.967]$} & [0.840] & {$[-0.350]$} \\
\hline \multirow[b]{3}{*}{$\mathrm{D}(\mathrm{CTR}(-1))$} & 0.647 & $(0.000)$ & 0.057 & $(0.046)$ & 0.139 & 0.064 \\
\hline & $(0.595)$ & $(0.011)$ & $(0.177)$ & $(0.241)$ & $(0.197)$ & $(0.080)$ \\
\hline & [1.088] & {$[-0.038]$} & [0.323] & {$[-0.190]$} & [0.707] & {$[0.804]$} \\
\hline \multirow[b]{3}{*}{$\mathrm{D}(\mathrm{CTR}(-2))$} & 0.241 & 0.011 & $(0.049)$ & 0.167 & 0.086 & 0.064 \\
\hline & $(0.537)$ & $(0.010)$ & $(0.160)$ & $(0.217)$ & $(0.178)$ & $(0.072)$ \\
\hline & {$[0.449]$} & [1.115] & {$[-0.308]$} & {$[0.771]$} & {$[0.486]$} & {$[0.891]$} \\
\hline \multirow[b]{3}{*}{$\mathrm{D}(\operatorname{ITR}(-1))$} & $(2.363)$ & 0.054 & $(0.656)$ & $(0.032)$ & $(0.428)$ & $(0.087)$ \\
\hline & $(1.570)$ & $(0.028)$ & $(0.467)$ & $(0.635)$ & $(0.520)$ & $(0.210)$ \\
\hline & {$[-1.505]$} & [1.905] & {$[-1.403]$} & {$[-0.050]$} & {$[-0.824]$} & {$[-0.412]$} \\
\hline \multirow[b]{3}{*}{$\mathrm{D}(\operatorname{ITR}(-2))$} & 0.699 & $(0.020)$ & $(0.035)$ & $(0.430)$ & $(0.264)$ & 0.058 \\
\hline & $(1.274)$ & $(0.023)$ & $(0.379)$ & $(0.515)$ & $(0.422)$ & $(0.170)$ \\
\hline & [0.549] & {$[-0.873]$} & {$[-0.092]$} & {$[-0.835]$} & {$[-0.625]$} & [0.340] \\
\hline \multirow[b]{3}{*}{$\mathrm{C}$} & 1.596 & 0.007 & $(1.270)$ & 0.310 & $(0.297)$ & 0.054 \\
\hline & $(1.241)$ & $(0.022)$ & $(0.369)$ & $(0.502)$ & $(0.411)$ & $(0.166)$ \\
\hline & [1.287] & [0.323] & {$[-3.438]$} & {$[0.618]$} & {$[-0.722]$} & [0.327] \\
\hline R-squared & 0.660 & 0.881 & 0.929 & 0.562 & 0.323 & 0.476 \\
\hline Adj. R-squared & 0.523 & 0.833 & 0.900 & 0.384 & 0.048 & 0.263 \\
\hline F-statistic & 4.788 & 18.258 & 32.063 & 3.160 & 1.176 & 2.236 \\
\hline \multicolumn{2}{|c|}{$\begin{array}{l}\text { Determinant resid covariance (dof } \\
\text { adj.) }\end{array}$} & \multicolumn{5}{|l|}{129.292} \\
\hline \multicolumn{2}{|c|}{ Determinant resid covariance } & \multicolumn{5}{|c|}{14.653} \\
\hline
\end{tabular}




\subsubsection{VECM (40-70)}

The output obtain from vector error correction model are given below:

Table 4. 5: Vector Error Correction Estimates (40-70 Group)

\begin{tabular}{|c|c|c|c|c|c|c|}
\hline \multicolumn{7}{|c|}{ Vector Error Correction Estimates } \\
\hline Cointegrating Eq: & \multicolumn{6}{|c|}{ CointEq1 } \\
\hline $\operatorname{SMC}(-1)$ & \multicolumn{6}{|c|}{1.000} \\
\hline \multirow[b]{3}{*}{$\mathrm{PS}(-1)$} & \multicolumn{6}{|c|}{16.354} \\
\hline & \multicolumn{6}{|c|}{$(9.135)$} \\
\hline & \multicolumn{6}{|c|}{$[1.790]$} \\
\hline \multirow[b]{3}{*}{ CPI $(-1)$} & \multicolumn{6}{|c|}{$(4.777)$} \\
\hline & \multicolumn{6}{|c|}{$(1.697)$} \\
\hline & \multicolumn{6}{|c|}{$[-2.815]$} \\
\hline \multirow[b]{3}{*}{$\operatorname{RIR}(-1)$} & \multicolumn{6}{|c|}{0.212} \\
\hline & \multicolumn{6}{|c|}{$(0.471)$} \\
\hline & \multicolumn{6}{|c|}{ [0.449] } \\
\hline & \multicolumn{6}{|c|}{2.082} \\
\hline & \multicolumn{6}{|c|}{$(1.785)$} \\
\hline CTR(-1) & \multicolumn{6}{|c|}{ [1.166] } \\
\hline & \multicolumn{6}{|c|}{$(2.340)$} \\
\hline & \multicolumn{6}{|c|}{$(0.705)$} \\
\hline $\operatorname{ITR}(-1)$ & \multicolumn{6}{|c|}{$[-3.316]$} \\
\hline $\mathrm{C}$ & \multicolumn{6}{|c|}{$(45.935)$} \\
\hline Error Correction: & D(SMC) & $\mathbf{D}(\mathbf{P S})$ & $\mathbf{D}(\mathbf{C P I})$ & D(RIR) & D(CTR) & D(ITR) \\
\hline \multirow[b]{3}{*}{ CointEq1 } & $(0.212)$ & $(0.003)$ & 0.023 & $(0.213)$ & $(0.005)$ & 0.050 \\
\hline & $(0.168)$ & $(0.003)$ & $(0.040)$ & $(0.119)$ & $(0.035)$ & $(0.047)$ \\
\hline & {$[-1.259]$} & {$[-1.105]$} & {$[0.573]$} & {$[-1.796]$} & {$[-0.134]$} & [1.049] \\
\hline \multirow[b]{3}{*}{$\mathrm{D}(\operatorname{SMC}(-1))$} & $(0.016)$ & $(0.000)$ & $(0.045)$ & 0.083 & $(0.013)$ & (0.017) \\
\hline & $(0.207)$ & $(0.004)$ & $(0.049)$ & $(0.145)$ & $(0.042)$ & $(0.058)$ \\
\hline & {$[-0.078]$} & {$[-0.093]$} & {$[-0.903]$} & {$[0.568]$} & {$[-0.295]$} & [-0.299] \\
\hline \multirow[b]{3}{*}{$\mathrm{D}(\operatorname{SMC}(-2))$} & 0.260 & 0.008 & $(0.050)$ & 0.019 & $(0.033)$ & $(0.019)$ \\
\hline & $(0.182)$ & $(0.003)$ & $(0.043)$ & $(0.128)$ & $(0.037)$ & $(0.051)$ \\
\hline & [1.426] & [2.436] & {$[-1.153]$} & [0.1479] & {$[-0.882]$} & {$[-0.380]$} \\
\hline & $(9.928)$ & $(0.167)$ & 0.295 & 3.189 & $(0.088)$ & 0.600 \\
\hline & $(9.902)$ & $(0.184)$ & $(2.360)$ & $(6.969)$ & $(2.032)$ & $(2.777)$ \\
\hline $\mathrm{D}(\mathrm{PS}(-1))$ & {$[-1.002]$} & {$[-0.910]$} & [0.125] & {$[0.458]$} & {$[-0.043]$} & {$[0.216]$} \\
\hline & 11.234 & $(0.030)$ & $(1.885)$ & $(3.234)$ & $(0.939)$ & 1.766 \\
\hline & $(9.716)$ & $(0.180)$ & $(2.315)$ & $(6.838)$ & (1.994) & $(2.724)$ \\
\hline $\mathrm{D}(\mathrm{PS}(-2))$ & {$[1.156]$} & {$[-0.166]$} & {$[-0.814]$} & {$[-0.473]$} & {$[-0.471]$} & [0.648] \\
\hline & $(0.580)$ & $(0.007)$ & $(0.477)$ & $(0.141)$ & $(0.013)$ & 0.019 \\
\hline & $(1.070)$ & $(0.020)$ & $(0.255)$ & $(0.753)$ & $(0.220)$ & $(0.300)$ \\
\hline $\mathrm{D}(\mathrm{CPI}(-1))$ & {$[-0.542]$} & {$[-0.348]$} & {$[-1.872]$} & {$[-0.187]$} & {$[-0.058]$} & {$[0.064]$} \\
\hline & 0.221 & $(0.001)$ & $(0.417)$ & $(0.257)$ & $(0.047)$ & 0.070 \\
\hline & $(0.924)$ & $(0.017)$ & $(0.220)$ & $(0.650)$ & $(0.190)$ & $(0.259)$ \\
\hline $\mathrm{D}(\mathrm{CPI}(-2))$ & [0.239] & {$[-0.075]$} & {$[-1.895]$} & {$[-0.395]$} & {$[-0.250]$} & {$[0.271]$} \\
\hline
\end{tabular}




\subsubsection{VECM (70+ Group)}

Table 4. 6: Vector Error Correction Estimates (70+ Group)

\begin{tabular}{|c|c|c|c|c|c|c|}
\hline \multicolumn{7}{|c|}{ Vector Error Correction Estimates } \\
\hline Cointegrating Eq: & \multicolumn{6}{|c|}{ CointEq1 } \\
\hline $\operatorname{SMC}(-1)$ & \multicolumn{6}{|c|}{1.000} \\
\hline \multirow[b]{3}{*}{ PS(-1) } & \multicolumn{6}{|c|}{$(283.566)$} \\
\hline & \multicolumn{6}{|c|}{$(800.632)$} \\
\hline & \multicolumn{6}{|c|}{$[-0.354]$} \\
\hline \multirow[b]{3}{*}{ CPI(-1) } & \multicolumn{6}{|c|}{$(1,079.089)$} \\
\hline & \multicolumn{6}{|c|}{$(297.243)$} \\
\hline & \multicolumn{6}{|c|}{$[-3.630]$} \\
\hline \multirow[b]{3}{*}{$\operatorname{RIR}(-1)$} & \multicolumn{6}{|c|}{990.900} \\
\hline & \multicolumn{6}{|c|}{ (325.963) } \\
\hline & \multicolumn{6}{|c|}{ [3.039] } \\
\hline & \multicolumn{6}{|c|}{386.807} \\
\hline & \multicolumn{6}{|c|}{$(150.922)$} \\
\hline CTR(-1) & \multicolumn{6}{|c|}{$[2.564]$} \\
\hline & \multicolumn{6}{|c|}{56.962} \\
\hline & \multicolumn{6}{|c|}{$(127.214)$} \\
\hline $\operatorname{ITR}(-1)$ & \multicolumn{6}{|c|}{$[0.448]$} \\
\hline $\mathrm{C}$ & \multicolumn{6}{|c|}{$(11,069.8)$} \\
\hline Error Correction: & D(SMC) & $\mathbf{D}(\mathbf{P S})$ & D(CPI) & D(RIR) & D(CTR) & D(ITR) \\
\hline \multirow[b]{3}{*}{ CointEq1 } & 0.001 & 7.87 & 0.000 & $(0.001)$ & $(0.000)$ & -7.13 \\
\hline & $(0.001)$ & $(2.0)$ & $(0.000)$ & $(0.000)$ & $(0.000)$ & $(8.0)$ \\
\hline & {$[0.519]$} & {$[0.387]$} & [2.489] & {$[-4.874]$} & {$[-1.812]$} & {$[-0.089]$} \\
\hline \multirow[b]{3}{*}{$\mathrm{D}(\mathrm{SMC}(-1))$} & $(0.345)$ & 0.000 & $(0.004)$ & $(0.012)$ & $(0.004)$ & 0.002 \\
\hline & $(0.121)$ & $(0.002)$ & $(0.011)$ & $(0.010)$ & $(0.010)$ & $(0.007)$ \\
\hline & {$[-2.859]$} & {$[0.217]$} & {$[-0.349]$} & {$[-1.228]$} & {$[-0.351]$} & {$[0.250]$} \\
\hline \multirow[b]{3}{*}{$\mathrm{D}(\mathrm{SMC}(-2))$} & $(0.465)$ & 0.002 & $(0.006)$ & $(0.008)$ & $(0.003)$ & 0.006 \\
\hline & $(0.141)$ & $(0.002)$ & $(0.013)$ & $(0.012)$ & $(0.012)$ & $(0.009)$ \\
\hline & {$[-3.291]$} & [1.048] & {$[-0.479]$} & {$[-0.655]$} & {$[-0.292]$} & [0.681] \\
\hline & $(7.276)$ & $(0.238)$ & $(1.379)$ & 2.085 & 1.198 & 0.167 \\
\hline & $(11.787)$ & $(0.183)$ & $(1.059)$ & $(0.975)$ & $(0.990)$ & $(0.719)$ \\
\hline $\mathrm{D}(\mathrm{PS}(-1))$ & {$[-0.617]$} & {$[-1.302]$} & {$[-1.302]$} & [2.138] & [1.211] & [0.232] \\
\hline & 15.209 & $(0.135)$ & $(1.116)$ & 1.557 & $(0.055)$ & $(0.525)$ \\
\hline & (11.736) & $(0.182)$ & $(1.055)$ & $(0.971)$ & $(0.986)$ & $(0.716)$ \\
\hline $\mathrm{D}(\mathrm{PS}(-2))$ & {$[1.296]$} & {$[-0.741]$} & {$[-1.058]$} & [1.603] & {$[-0.056]$} & {$[-0.733]$} \\
\hline & 0.113 & $(0.006)$ & $(0.357)$ & $(0.417)$ & $(0.058)$ & $(0.132)$ \\
\hline & $(2.022)$ & $(0.031)$ & $(0.182)$ & $(0.167)$ & $(0.170)$ & $(0.123)$ \\
\hline $\mathrm{D}(\mathrm{CPI}(-1))$ & {$[0.056]$} & {$[-0.182]$} & {$[-1.965]$} & {$[-2.491]$} & {$[-0.338]$} & {$[-1.072]$} \\
\hline & 1.059 & $(0.003)$ & $(0.197)$ & $(0.015)$ & $(0.209)$ & $(0.074)$ \\
\hline & $(1.750)$ & $(0.027)$ & $(0.157)$ & $(0.145)$ & $(0.147)$ & $(0.107)$ \\
\hline $\mathrm{D}(\mathrm{CPI}(-2))$ & [0.605] & {$[-0.102]$} & {$[-1.253]$} & {$[-0.104]$} & {$[-1.423]$} & {$[-0.693]$} \\
\hline
\end{tabular}


The empirical investigation of this study by use of VAR and VECM models exhibits that there is a significant cointegrated relationship between stock market capitalization to GDP ratio and political stability, inflation, real interest rate, corporate tax rate and indirect tax rate. This relationship is also supported by literature on investment theories and paradigms. The stock market is considerably undervalued in Pakistan as compared to other emerging economies. In absence of stable financial institutions, this shows comparative inability in facilitating savers and investors towards provision of pooled investments in stock markets which may enhance value or them and wealth for the economy.

\section{Conclusion and Recommendations}

This study concludes that the impact of Inflation, corporate tax rate and indirect tax rate significantly enhances the market capitalization of stock market. Stable corporate tax rate helps the corporations to expand and enhance their capital assets in a short as well as long run. It also increases the market capitalization which ultimately enhances the economic growth and helps to boost up the capacity of the stock market.

This research is helpful for the firms and investors who are the part of this economy. This study also has implications for the policy makers and financial advisors, who are liable to develop better and more efficient policies targeted towards capacity building of stock market as a trigger for economic growth.

This region shall be considered as the key context of research in the coming future for economists and researchers of financial development and economic growth. Stock market capitalization to GDP can be considered a direct indicator of economic growth, used to evaluate economic development and financial depth of a country. Pakistan is rich in resources, with a handicap of political instability. The monetary and fiscal policies of the Government shall target capacity building measures of the stock market in future to play a vital role in growth and development of the country.

\section{References}

Delali, Charles Komla. 2007. "Links Between Stock Market Development and Key Economic Growth Variables: The Case of Selected African," no. March: 7-9.

Foresti, Pasquale, and Oreste Napolitano. 2017. "On the Stock Market Reactions to Fiscal Policies." International Journal of Finance and Economics 22 (4): 296-303. https://doi.org/10.1002/ijfe.1584.

Hariz, Muhammad, Afiq Bin, Nor Harswari, and Sahibzada Muhammad Hamza. 2017. "The Impact of Interest Rate on Economic Development: A Study on Asian Countries." International Journal of $\begin{array}{llllll}\text { Accounting } \quad \& \quad \text { Business } & \text { Management } & 5 & \text { (1): }\end{array}$ https://doi.org/24924/ijabm/2017.04/v5.iss1/180.188.

Iqbal, Javed. 2012. "Stock Market in Pakistan: An Overview." Journal of Emerging Market Finance 11 (1): 61-91. https://doi.org/10.1177/097265271101100103.

Mao, Yajuan, and Rongfu Wu. 2007. "Does the Stock Market Act As a Signal for Real Activity? Evidence From Australia." Economic Papers: A Journal of Applied Economics and Policy 26 (2): 180-92. https://doi.org/10.1111/j.1759-3441.2007.tb01015.x.

Moyo, Clement, and Pierre Le Roux. 2018. "Interest Rate Reforms and Economic Growth: The Savings and Investment Channel.” MPRA Paper, no. 85297.

Nazir, Mian Sajid, Muhammad Musarat Nawaz, and Usman Javed Gilani. 2010. "Relationship between Economic Growth and Stock Market Development.” African Journal of Business Management 4 (16): 3473-79.

Othman Abbas, Ali. 2016. "Impact of Stock Market on Economic Growth Evidence: Dar-Es Salaam 50 
Stock Exchange - Tanzania." Journal of Finance and Accounting 4 (6): 321. https://doi.org/10.11648/j.jfa.20160406.12.

Paramati, Sudharshan Reddy, and Thanh Pham Thien Nguyen. 2019. "Does Financial Market Growth Improve Income Distribution? A Comparison of Developed and Emerging Market Economies of the Global Sample." International Journal of Finance and Economics 24 (1): 629-46. https://doi.org/10.1002/ijfe.1683.

Personal, Munich, and Repec Archive. 2008. "Munich Personal RePEc Archive Stock Market in Pakistan : An Overview Stock Market in Pakistan : An Overview," no. 11868.

Perveen, Shahida, and Mustaghis-ur- Rahman. 2018. "Impact of Fiscal and Monetary Policies on Stock Market Performance: An Empirical Study of Pakistan Stock Exchange.” Journal of Finance \& Economics Research 3 (2): 2-23. https://doi.org/10.20547/jfer1803201.

Saeed, Muhammad. 2017. "Impact of Political Stability, Government Effectiveness AndControl of Corruption on Stock Markets of South Asia.” Journal of the Punjab University Historic Society 30 (1): 226-38.

Shula, Kampamba. 2017. "The Impact of GDP, Inflation, Interest and Exchange Rates GDP on the Stock Market in Zambia,” no. March. https://doi.org/10.13140/RG.2.2.11457.56160.

Soydemir, Gökçe. 2000. "International Transmission Mechanism of Stock Market Movements: Evidence from Emerging Equity Markets." Journal of Forecasting 19 (3): 149-76. https://doi.org/10.1002/(sici)1099-131x(200004)19:3<149::aid-for735>3.3.co;2-3. 
